\title{
EFFECT OF THE METHOD OF POSTPARTUM ADMINISTRATION OF OXYTOCIN OR PGF2AON THE DROP OF RETAINED PLACENTA IN COWS AND SUBSEQUENT REPRODUCTIVE AND REPRODUCTIVE PERFORMANCE
}

Abou-Aiana ${ }^{2}$, R. M, Hammad ${ }^{1}$, M. E. R. Sh. A. Gabr. ${ }^{1}$, A. M. Amer ${ }^{2}$, E.A.A.Ahmadi2 and A. H. A. Alharoon ${ }^{2}$

${ }^{1}$ Animal Production Department, Faculty of Agriculture, Tanta University, Egypt

${ }^{2}$ Animal Production Research Institute, Dokki, Giza, Egypt

\section{ABSTRACT}

Fourty Friesian cows(about 5-7 years and 450- $550 \mathrm{~kg}$ weight) with dystocia and retained placenta were used in the present study. The experimental animals $(n=40)$ were divided into five groups, $(8$ each). The first group was intramuscularly (I.M) injected with saline solution and kept as a control group, second group was I.M injected with $50 \mathrm{IU}$ of oxytocin, third group was I.M injected with $500 \mu \mathrm{g}$ of $P G F_{2 \alpha}$ analogue, fourth group was administered $50 \mathrm{IU}$ oxytocin then $10 \mathrm{~mL} 0.9 \% \mathrm{NaCl}$ via intra-umbilical artery. The fifth group was administered500 $\mu \mathrm{g} P G F 2 \alpha$ then $10 \mathrm{~mL} 0.9 \% \mathrm{NaCl}$ via intra-umbilical artery. All animals in the different groups (control and treated) were administeredafterl-2 hours of calving. Time ( $h$ ) of placenta expulsion, Time $(d)$ of uterine involution, Postpartum first estrus/service interval(PPFEI),Service period (SP), Daysopen (DO), Number of services per conception (NSC), conception rate $(C R)$ were recorded. The obtained results showed that, the time for expulsion of placenta and uterine involution, PPFEI, PPFSI, DO, SP, NSC were significantly $(P<0.05)$ shorter in $P G F_{2 \alpha}(I U A)$ treatment group compared other groups while, all treatment groups were significantly $(P<0.05)$ shorter than the control group. The conception rate was significantly the highest in $P G F_{2 \alpha}$ (IUA) group and significantly higher $(P<0.05)$ in treatment groups than that in control group. Milk yield in 90 days was significantly $(P<0.05)$ the highest in $P G F_{2 \alpha}(I U A)$ group and significantly higher $(P<0.05)$ in treatment groups than that in control group. In conclusion, administration of $500 \mu \mathrm{g} P G F 2 \alpha$ then $10 \mathrm{~mL} 0.9 \% \mathrm{NaCl}$ via umbilical artery immediately after expulsion of the fetus induce early expulsion of fetal membrane and improving the reproductive and productive performance of Friesian cattle experienced retention of fetal membrane.

Key words: cow, $\mathrm{PGF}_{2 \alpha}$, oxytocin, umbilical cord, uterine involution 


\section{INTRODUCTION}

Fetal membranes are normally expelled within 3 to $8 \mathrm{~h}$ after parturition and their retention for more than 12 to $24 \mathrm{~h}$ is considered retained placenta (RP). The incidence of RP in cows ranges from $2 \%$ to $6 \%$, with an average of approximately $10 \%$ (Stephen., 2008). Dystocia increases the percentage of cows affected by RP. The economic impactof RPis reflected in loss of milk, impaired fertility, and high culling rate. The consequences of RP are an increase in the calving to first service interval, a reduction in the pregnancy rate to first service, an increase in the number of services per conception, and a longer calving interval (Laven and Peters, 1996). The normal drop of placenta after parturition requires adequate and regular uterine contractions. A deficiency in secretions of PGF2 $\alpha$, oxytocin, or serum $\mathrm{Ca}$ concentration, which maintain adequate contraction of the uterus, may cause RP, increase the risk of dystocia, and delay the involution of the uterus (Akar and Yildiz, 2005and Hurleyand Doane, 1989). High concentrations of PGF $2 \alpha$ and PGE2 are produced by the uterus during the early postpartum period in cows and may play an important role in both placental separation and uterine involution (Slama et al., 1994). Many factors have been implicated in the production of RP and many of these are interrelated, such as uterine atony, abortion, delayed gestation, dystocia, high environmental temperatures, early parturition, infections, twin pregnancy, and vitamin and mineral deficiencies (Akar and Yildiz, 2005). For the treatment and prevention of RP, injections of ecbolic drugs and enzymes such as oxytocin, prostaglandin $\mathrm{F}_{2 \alpha}$ have been administered within $24 \mathrm{~h}$ of parturition (Mollo et al., 1997). 
Guerin et al., (2004) have shown collagenase application via umbilical artery after parturition to reduce the time and increase the rate of fetal membrane removal in cows.If RP is left untreated in women, there is high risk of maternal death. However, manual removal of the placenta is an invasive procedure with its own serious complications of hemorrhage, infection, or genital tract trauma (Carroli and Bergel., 2001). Therefore, the injection of oxytocin, ergometrine, or PGF $2 \alpha$ via the intra-umbilical vein has been suggested as an alternative treatment for women experiencing RP. The method relies on the injected solution passing down the umbilical cord and through the placental bed to contract the myometrium behind the placenta, thereby causing its detachment Weeks, (2003). Sivalingam and Surinder, (2001) suggested that intra-umbilical vein injections of oxytocin or PGF $2 \alpha$ may be a beneficial, cheap, nonaggressive, nonsurgical method for treating RP in women.

The present study was carried out to evaluate the effect of injection via intra- umbilical artery of oxytocin and PGF $2 \alpha$ on time and rate of placenta retention after parturition in Friesian cows and subsequent productive and reproductive performance.

\section{MATERIALS AND METHODS}

The present study was carried out in Private Farm, Al-Thoraya Farm for Animal Production in Kuniaysit Damsheet, Gharbiya Governorate during the period from December, 2016 to July, 2017. The study was performed on 40 cows of aged 5-7 years and weighed450- 550 $\mathrm{kg}$.Most of the cows had dystocia in thecurrent calving and all animals had retained placenta in previous calving based on the farm records. The 
experimental animals $(\mathrm{n}=40)$ were divided into five groups $(8$ cows each):G1 where cows were intra-muscularly (I.M) injected with $10 \mathrm{~mL}$ $0.9 \% \mathrm{NaCl}$ and considered as a control group; $\mathbf{G} 2$ where cows were intramuscularly (I.M) injected with $50 \mathrm{IU}(5 \mathrm{ml})$ of oxytocin (ADWIA Co. S.A.E., 10th of Ramadan City, Egypt). Each $1 \mathrm{ml}$ contains $10 \mathrm{IU}$ of oxytocin; G3 where cows were intra-muscularly (I.M) injected with 500 $\mu \mathrm{g}(2 \mathrm{ml})$ of prostaglandin analogue(Estromate, Novartis Pharm, S.A.E. Cairo, under license from Novartis pharm, AG. Basle, Switzerland). Each $1 \mathrm{ml}$ contains $250 \mu \mathrm{g}$ of d-cloprostenol; G4 wherecows were administered $50 \mathrm{IU}(5 \mathrm{ml})$ oxytocin and $10 \mathrm{~mL} 0.9 \% \mathrm{NaCl}$, respectively. Each $1 \mathrm{ml}$ contains 10 IU of oxytocin, via intra-umbilical artery immediately after expulsion of the fetus. Injection was applied to the umbilical cords, whose arteries and veins were massaged for $5 \mathrm{~min}$ for blood remnant removal. The injection to the umbilical cord artery was carried out as near as possible to the uterus using a spinal needle (22 G, $0.70 \times 89 \mathrm{~mm}$, Exelint International Co., Los Angeles, CA, USA) Additionally, in order to better introduce the injected substances (oxytocin, $\mathrm{NaCl}$ ) to the uterus, the upward umbilical artery was massaged upwardly after each application and then the umbilical artery was clamped Akar et al. (2012); G5 where cows were administered 500 $\mu \mathrm{g}(2 \mathrm{ml})$ Prostaglandin and $10 \mathrm{~mL} 0.9 \% \mathrm{NaCl}$, respectively (Estromate, Novartis Pharm, S.A.E. Cairo, under license from Novartis pharm, AG. Basle, Switzerland). Each $1 \mathrm{ml}$ contains $250 \mu \mathrm{g}$ of d-cloprostenol, via intra-umbilical artery immediately after expulsion of the fetus. Injection was applied to the umbilical cords. . Injection was applied to the umbilical cords, whose arteries and veins were massaged for $5 \mathrm{~min}$ for blood remnant removal. The injection to the umbilical cord artery was 
carried out as near as possible to the uterus using a spinal needle (22 G, $0.70 \times 89 \mathrm{~mm}$, Exelint International Co., Los Angeles, CA, USA) Additionally, in order to better introduce the injected substances ( $\mathrm{PGf}_{\mathbf{2 a}}$, $\mathrm{NaCl})$ to the uterus, the upward umbilical artery was massaged upwardly after each application and then the umbilical artery was clamped Akar et al. (2012).

\section{Feeding and management systems:}

Animals were fed on diet that met both maintenance and productionrequirement .The type of offered feed included concentrate feed mixture (CFM) plus fresh Egyptian clover (Trifolium alixandrinum, 2th-4th cut) and rice straw (RS).

\section{Milking and sucking system:}

During the $1^{\text {st }}$ week post-partum, calves in all groups were left with their dams for 3-4 days to receive the colostrum, and then they were artificially suckled until weaning. Thereafter, all cows were artificially milked twice daily at 6:00 and 18:00 h by Automatic milking.

\section{Reproductive performance:}

\section{Time (hr) for placenta expulsion:}

The time (hours) from calving to full expulsion of placenta was recorded in all animals.

\section{Time (d) required for uterine involution completion:}

The interval (days) from calving for completion of uterine involution was recorded. Manual examination of the genitalia per rectum was performed in days $10,15,22,25,32,40,48$, and 55 of postpartum until symmetry of both gravid and non-gravid horns. 


\section{Postpartum first estrus interval (PPEI):}

The interval (days) from calving to first estrous activity was determined. Estrous was detected byvisual observation.

\section{Post-partum first service interval (PPFSI):}

The interval (days) from calving to first service of cows was recorded.

\section{Conception rate $(\mathrm{CR})$ :}

Conception rate $(\%)=\{$ conceived animals $(n) \div$ served animals (n) $\} \times 100$.

\section{Days open (DO):}

It was calculated by subtracting the date of calving from the date of fertile service

\section{Number of services per conception (NSC):}

The number of services per conception was calculated.

\section{Productive performance:}

\section{Average (kg) Milk yield in 90 days after calving:}

\section{8-Statistical analysis:}

Analyzed by Completely Randomized Block Design (CRBD) in the case of replicates are not equal and the case of replicates are equal. Data were represented in mean \pm standard deviation values. (Least Significant Difference - LSD) test was performed for comparing values among the groups. $\mathrm{P}<0.05$ was considered to be significant. The obtained data were statistically analyzed according to Snedecor and Cochran(1982) using computer program of SAS (2004). 


\section{RESULTS AND DISCUSSION}

\section{Time (hr) for expulsion of placenta (RP):}

Thetime for expulsion of placenta in treatment groups was significantly $(\mathrm{P}<0.05)$ shorter than that in control group (Table 1$)$. While within the treatment groups, it was significantly $(\mathrm{P}<0.05)$ the shortest in G5 .Our results came in agreement with those of Alharoon (2018), Khatri et al. (2013), Akar et al. (2012) and Rehametal. (2010) who reported that the mean time for fetal membrane drop inanimalstreated with PGF2 $\alpha$ (IM) was shorter than those treated with oxytocin and control group (3.0, 4.45 and 6.30 hours) respectively. Molloet al. (1997) showed that the intramuscular administration of oxytocin immediately after delivery and again 2-4 h later reduced the incidence of RP significantly in Holstein cows and consequently the occurrence of endometritis post-RP. Stocker and Waelchli (1993) reported that intramuscular administration of $25 \mathrm{mg}$ dinoprost immediately after parturition reduced the incidence of RP significantly in cows with dystocia. Haffner et al. (1998) concluded that intra-umbilical artery injection of collagenase was a safe and potentially effective treatment for RP in mares. Bider et al. (1996) reported that intraumbilical vein injection of $20 \mathrm{mg}$ PGF $2 \alpha$ might be a beneficial method for treating RP. Although oxytocin and prostaglandin intra-umbilical artery administration, applied to cows with dystocia for the first time in this study, appeared to have a positive effect on the time and rate of drop of fetal membranes. In the present study, the time required for expulsion of fetal membranes was the shortest in PGF2 $\alpha$ (IUA) treated animals compared with that in four other groups. These results fall in the range reported by Hussain (1983) in buffaloes and Alharoon, 2018 and 
Muhammad and Muhammad (2002) in cattle. Early expulsion of fetal membranes in the G5 might have been due to prolonged uterine contraction induced by $\mathrm{PGF}_{2 \alpha}$.

\section{Average time (d) required for completion of uterine involution in (RP):}

The time for completion of uterine involution in treatment groups as shown in Table $(1)$ was significantly $(\mathrm{P}<0.05)$ shorter than that in control group, while within the treatment groups, it was significantly $(\mathrm{P}<0.05)$ the shortest in G5.In agreement with the present results, Alharoon, 2018, Khatri et al. (2013) and Hanan (2015) reported that the intervalto uterine involution in PGF2 $\alpha$-treated cows was shorter than that recorded for either oxytocin-treated or control cows. Uterine Involution is normally completed between 26 to 52 days postpartum but changes after 20 to 25 days are often imperceptible (Drillich et al., 2006). Inadequate production of endogenous prostaglandin has been associated with delay in uterine involution. The beneficial effect of PGF $2 \alpha$ administered postpartum is due to myometrium contraction thereby accelerated uterine involution (Hirsbrunner 2003).

Table (1): Means $\pm S E$ of time required for placental drop and Days to uterine involution in G1, G2, G3, G4 and G5 cows.

\begin{tabular}{|c|c|c|c|c|c|}
\hline \multirow{2}{*}{ Items } & \multicolumn{5}{|c|}{ Treatments } \\
\cline { 2 - 6 } & $\mathbf{G 1}$ & $\mathbf{G 2}$ & $\mathbf{G 3}$ & $\mathbf{G 4}$ & $\mathbf{G 5}$ \\
\hline $\begin{array}{c}\text { Time (hr) of placental } \\
\text { repulsion }\end{array}$ & $16.56^{\mathrm{a}} \pm 0.86$ & $8.88^{\mathrm{b}} \pm 1.32$ & $7.50^{\mathrm{b}} \pm 0.80$ & $4.84^{\mathrm{c}} \pm 0.37$ & $3.44^{\mathrm{c}} \pm 0.26$ \\
\hline $\begin{array}{c}\text { Days to uterine } \\
\text { involution }\end{array}$ & $51.75^{\mathrm{a}} \pm 1.39$ & $38.63^{\mathrm{b}} \pm 0.75$ & $30.13^{\mathrm{d}} \pm 0.97$ & $35.13^{\mathrm{c}} \pm 1.78$ & $29.63^{\mathrm{d}} \pm 0.89$ \\
\hline
\end{tabular}

a,b,c,d: Means with the different superscripts in the same row, differ significantly $(\mathrm{P}<0.05)$.

Different letters on the same row indicate significance $(\mathrm{P}<0.05)$

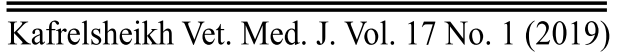




\section{Interval to first estrous:}

The interval to first estrus was significantly $(\mathrm{P}<0.05)$ shorter in all treated groups compared with the control $(\mathrm{P}<0.05)$, while within the treatment groups, it was significantly $(\mathrm{P}<0.05)$ the shortest in PGF2 $\alpha$ (IUA) group Table (2). In agreement with the present results, Alharoon, (2018), and Khatrietal., (2013) reported that animals which were treated with PGF2 $\alpha$ (IM) showed shorter interval than that treated with oxytocin and control groups respectively. In contrast with the present results, Abdel-khalek et al., (2013) reported that PPFEI of multiparous cows was longer in treatment groups with Oxytocin and Prostaglandin (OXY and PG) than in control group respectively. That is consistent with the findings of Hanan (2015) who reported a short time (days) required for postpartum first estrous activityin $1^{\text {st }}$ season cows which treated with oxytocin and PGF2 $\alpha$ compared with control respectively.

\section{Interval to first estrous service:}

The intervalas shown in Table (2) was significantly $(\mathrm{P}<0.05)$ shorter in treatment groups than that in control, while within the treatment groups, it was numerically the shortest in PGF2 $\alpha$ (IUA) group. These results are in agreement with Alharoon, (2018)and Hanan (2015) who indicated a shorter time that required for first servicein season $1^{\text {st }}$ cows which were treated with oxytocin and PGF2 $\alpha$ than in control group respectively. Disagree with the present results, Abdel-khalek et al., (2013) reported that PPFSI of multiparous cows was longer in treatment groups (oxytocin and PGF2 $\alpha$ ) than in control group respectively. This may be due to the time and dose of injection and number of treated cows. Changes in hormonal levels during post-partum period include pituitary gonadotrophins (FSH and LH), Oxytocin (oxy), Steroid hormones (E and 
P4) and Prostaglandin (PGF2 $\alpha$ ) is essential to understand the factors responsible for initiation of cyclic ovarian activity following parturition. These changes have impact on postpartum reproductive activity (El-Wishy., 2007). An increased rate of uterine involution is associated with earlier resumption of ovarian activity (Mateus et al.,2002), which is in turn important for increasing pregnancy rate to first service Thatcher et al. (2006) in accordance with the present results of cows in $\mathrm{G} 2$.

\section{Conception rate (\%):}

The conception rate as shown in table (2) was significantly $(\mathrm{P}<0.05)$ higher in treatment groups than that in control group, while within the treatment groups, it was significantly the highest in PGF2 $\alpha$ (IUA) group. According to the present study, incidence of uterine involution was almost associated with early resumption of ovarian activity. In this respect, multiparous cows treated with oxytocin or PGF2 $\alpha$ showed early uterine involution with the highest CR as compared to control Alharoon (2018) and Abdel-khalek et al.(2013).

\section{Average time (d) of open days:}

The average time (D) of days openas shown in Table (2) was significantly lower $(\mathrm{P}<0.05)$ in treatment groups than that in control group, while within the treatment groups, it was numerically the shortest in PGF2 $\alpha$ (IUA) group. In agreement with the present results Alharoon (2018) and Hanan (2015) found that days open of primiparous cows was shorter in treatment groups. Many factors may result in an increase in calving to conception intervals include inadequate nutrition, uterine infection, poor estrus detection or decision of the dairy man to delay the first service beyond 60- 80 days postpartum (Williamson et al., 1980). 
Table (2): Indices of reproductive performance in G1, G2, G3, G4 and G5 cows.

\begin{tabular}{|c|c|c|c|c|c|}
\hline \multirow{2}{*}{ Items } & \multicolumn{5}{|c|}{ Treatments } \\
\cline { 2 - 6 } & $\mathbf{G 1}$ & $\mathbf{G 2}$ & $\mathbf{G 3}$ & $\mathbf{G 4}$ & G5 \\
\hline $\begin{array}{c}\text { Interval to } \\
\text { firstestrus }\end{array}$ & $72.00^{\mathrm{a}} \pm 06.98$ & $55.00^{\mathrm{b}} \pm 00.96$ & $48.63^{\mathrm{b}} \pm 00.78$ & $47.63^{\mathrm{b}} \pm 01.49$ & $37.25^{\mathrm{c}} \pm 00.70$ \\
\hline $\begin{array}{c}\text { Interval to } \\
\text { first service }\end{array}$ & $74.75^{\mathrm{a}} \pm 06.97$ & $58.63^{\mathrm{b}} \pm 00.78$ & $51.63^{\mathrm{bc}} \pm 00.75$ & $49.50^{\mathrm{c}} \pm 01.30$ & $38.25^{\mathrm{c}} \pm 00.96$ \\
\hline $\begin{array}{c}\text { Conception } \\
\text { rate (\%) }\end{array}$ & $100^{\mathrm{a}}$ & $87.50^{\mathrm{b}}$ & $75.00^{\mathrm{d}}$ & $87.50^{\mathrm{b}}$ & $62.00^{\mathrm{c}}$ \\
\hline $\begin{array}{c}\text { Days open } \\
\text { Services } \\
\text { perconception }\end{array}$ & $03.00^{\mathrm{a}} \pm 00.31$ & $02.00^{\mathrm{b}} \pm 00.21$ & $01.30^{\mathrm{c}} \pm 00.21$ & $01.50^{\mathrm{bc}} \pm 00.22$ & $01.40^{\mathrm{c}} \pm 00.18$ \\
\hline $\begin{array}{c}\text { Milk yield in } \\
90 \mathrm{~d}(\mathrm{~kg})\end{array}$ & $0553.50^{\mathrm{d}} \pm 09.60$ & $0627.80^{\mathrm{c}} \pm 06.80$ & $0634.10^{\mathrm{c}} \pm 05.80$ & $0861.90^{\mathrm{b}} \pm 16.00$ & $1010.30^{\mathrm{a}} \pm 19.90$ \\
\hline
\end{tabular}

a,b,c,: Means with the different superscripts in the same row, differ significantly $(\mathrm{P}<0.05)$.

\section{Number of services per conception (SPC):}

The number of services per conception (SPC) as shown in Table (2) was significantly $(\mathrm{P}<0.05)$ lower in treatment groups than in control group, while within the treatment groups, it was numerically the lowest in PGF2 $\alpha$ (IM) group. These results are in agreement with those of Alharoon, (2018) and Hanan (2015) who found that, the Services preconception (SPC) and Services period length (SPL) were significantly $(\mathrm{p}<0.05)$ lower in oxytocin group than control group. The present results of SPC are within control values as reported in Fresian cows raised in Egypt, being 1.4 (Wafa, 2004, Ganah, 2000, AbdelKafrelsheikh Vet. Med. J. Vol. 17 No. 1 (2019) 
Razek et al. 2005) and 2.75 services /cow (Abdel-khalek, 2003). According to the present results, treatment of cows at calving with oxytocin shortened SPC, in association with higher conception rate.

\section{Average (kg) Milk yield in 90 days after calving:}

The average amount of milk yield in 90 days after calving as shown in Table (2).It was significantly higher $(\mathrm{P}<0.05)$ in treatment groups than that in control group.Within the treatment groups, it was significantly $(\mathrm{P}<0.05)$ the highest in $\mathrm{PGF}_{2 \alpha}$ (IUA) group. Retained placenta had a significant negative effect on milk yield. Thiscamein agreement withresults of Alharoon, (2018), Wafa., (2004) andBar-Peled et al. (2005)who found that milk yield decreased by 172, 232 and $302 \mathrm{~kg}$ with retained placenta. The incidence of RFM can be reduced by administration of $500 \mu \mathrm{gGF}_{2 \alpha}$ or $50 \mathrm{IU}$ oxytocin via umbilical artery after parturition. This will significantly improve the reproductive and productive performance of Fresian cattle experienced retention of fetal membranes compared to intra-muscular Injection of $500 \mu \mathrm{g} \mathrm{PGF}_{2 \alpha}$ or 50 IU oxytocin.

In conclusion, administeration of $500 \mu \mathrm{g} \mathrm{PGF}_{2 \alpha}$ followed by $10 \mathrm{~mL}$ $0.9 \% \mathrm{NaCl}$ via intra-umbilical artery immediately after expulsion of the fetus induce early expulsion of fetal membrane and improving the reproductive and productive performance of Friesian cattle experienced retention of fetal membrane. Therefore, It can be recommend toadministered $500 \mu \mathrm{g}$ PGF $2 \alpha$ then $10 \mathrm{~mL} 0.9 \% \mathrm{NaCl}$. 


\section{REFERENCES}

- Alharoon, A. H. A.(2018).Comparison between application of injection via umbilical artery and intra-muscular injection of oxytocin and prostaglandinF $\mathrm{F}_{2 \alpha}$ on time and rate of placenta separation after parturition.M. Agri. Sci: Thesis, Animal Production Department, Faculty of Agriculture, Tanta University, Egypt.

- Abd El-Razek, I.M.; Mentally, A.M. and Shitta, A.A. (2005). Effect of monensin on reproductive performance and milk production in lactating dairy cows. J. Agric. Res., Tanta Univ., 31:15.

- Abdel-khalek, A.E. (2003). Productive and reproductive performance of primiparous and multiparous Friesian cows fed rations supplemented with yeast culture (Yea-sace1026).Egypt. J. Nutri. And Feeds, 6 (special Issue): 1095.

- Abdel-khalek, A.E.; El-Harairy, M. A.; Mehrez, A. F.; Foad, W.F. (2013). Uterine involution and reproductive performance of lactating Friesian cows at calving J. Anim. and poult. Prod., Mansoura University, 6:350-362.

- Akar, Y.and Yildiz,H. (2005). Concentrations of some minerals in cows with retained placenta and abortion Turki. J. Vet. Anim. Sci., 29:1157-1162.

- Akar, O.; Kizil, O. Saat, N. andYuksel, M. (2012). The effect of Oxytocin and cloprostenol application via umbilical artery immediately after dystocia on time and rate of fetal membrane removal in cows. Turk. J. Vet. Anim. Sci.; 36(3): 275-281. 
- Bar-Peled, U.; Maltz, E.; Bruckental, I.; Folman, Y.; Kali, Y.; Gacitua, H.; Lehrer, A.; Knight, C.; Robinzon, B.; Voet, H. and Tagar, H. (2005). Relationship between frequent milking or suckling in early lactation and milk production of high producing dairy cows. J. Dairy Sci. 78:2726-2736

- Bider, D.; Mordechani, D. and Mordechai, G. (1996). Intraumbilical vein injection of prostaglandin F2 $\alpha$ in retained placenta. Europ. J. obstet. Gynecol. Reprod. boil. 64: 59-61.

- Carroli, G.; Belizan, J. M.; Grant, A.; Gonzalez, L.; Campodonico, L. and Bergel, E. (1998). Intra-umbilical vein injection and retained placenta: evidence from a collaborative large randomised controlled trial. Grupo Argentino de Estudio de Placenta Retenida. Br. J. Obstet. Gynaecol, 105: 179-185 .

- Carroli, G. and Bergel, E. (2001). Umbilical vein injection for management of retained placenta. Cochrane Datatbase syst. Rev., 4: 1337.

- El-Wishy, A.B .(2007). The postpartum buffalo: I. Endocrinological changes and uterine involution. Anim. Reprod. Sci., 97:201-215.

- Drillich, M. I.; Mahlstedt, M.; Reichert, U.; Tenhagen, B. A. and Euwieser, W. (2006). Strategies to improve the therapy of retained fetal membranes in Dairy cows. J. Dairy Sci., 82:27-635.

- Ganah, B.A.H. (2000). Effect of improved management systems on productivity of Fresian Cattle (A. study on improving postpartum reproductive performance). M.Agri. Sci.Thesis,Fac. Agric., Mansoura University., Egypt. 
- Guerin, P.; Badinand, F.; Bosc, L.; Thiebault, J. J.; DelignetteMuller, M. L.; and Menezo, Y. (2004). Effect of injecting collagenase into the uterine artery during a caesarean section on the placental separation of cows induced to calve with dexamethasone. Vet. Rec., 154: 326-328.

- Haffner, J. C.; Fecteau, K. A.; Held, J. P.; and Eiler, H. (1998). Equine retained placenta: technique for and tolerance to umbilical artery injections of collagenase. Theriogenology, 49: 711-716.

- Hanan, I.E.I.(2015). Some hormonal treatments affecting uterine involution of primiparous cows. M. Agri. Sc. Thesis. Fac. Agric. Tanta Univ., Egypt.

- Hirsbrunner, G.; Knutti, B.; Kupfer, U.; Burkhardt, H.; and Steiner, A. (2003). Effect of prostaglandin E2, D-Cloprostenol and prostaglandin E2 in combination with D-cloprostenol on uterine motility during diestrus in experimental cows.Anim. Reprod. Sci. 79: 17-32.

- Hurley, W. L. and Doane, R.M .(1989). Recent developments in the roles of vitamins and minerals in reproduction. J. Dairy Sci., 72: 784-804.

- Hussain, S. O. (1983). Treatment and prevention of retained placenta in dairy cattle. $15^{\text {th }}$ FAO/SIDA International Postgraduate course on Anim. Reprod. 2:8-29. 
- Khatri, P.; Tunio, S. A.; Kaka, I.; Samo, M. U.; Bhutto, B. and Memon, M. R. (2013). Effect of Exogenous PGF2 $\alpha$ and Oxytocin on Postpartum Anestrus and Uterine Involution in Kundhi Buffaloes .J. Anim. Prod. Adv., 3(4): 158-163.

- Laven, R. A. and Peters, A. R. (1996). Bovine retained placenta: aetioligy, pathogensis, and economic loss. Vet. Rec. 139:465-471.

- Mateus, L.; Lopes, D, A.; Costa, L.; Bernardino, F. and Silva, J. (2002). Influence of puerperal uterine infection on uterine involution and postpartum ovarian activity in dairy cows. Reprod. Domest. Anim., 37:31-5.

- Mollo, A.; Veronesi, M. C.; Cairoli, F. and Soldano, F. (1997). The use of oxytocin for the reduction of cow placental retention, and subsequent endometritis. Anim. Reprod. Sci., 48: 47-51.

- Muhammad, M. A. and Muhammad, D. K .(2002). Treatment of retained fetal membranes in cattle. National conference on factors limiting on dairy production in Pakistan. University of Agriculture, Faisalabad, Punjab, 8-9 April.

- Waheeb, R. S.; Hussein, F. M.; El-Amrawi, G. A. and El-Hammady, E. A. (2010). Retained Fetal Membranes In Holstein Cows: Economical evaluation of different therapeutic protocols under Egyptian conditions" International Scientific Publications: Agriculture and Food Volume 2, ISSN 1314-8591. 
- Sivalingam, N. and Surinder, S. (2001). Is there a place for intraumbilical oxytocin for the management of retained placenta? Med. J. Malaysia, 56: 451-459.

- Slama, H.; Vaillancourt, D. and Goff, A.K. (1994). Control of in vitro prostaglandin F2 alpha and E2 synthesis by caruncular and all antochorionic tissues from cows that calved normally and those with retained fetal membranes. Dom. Anim. Endocr., 11: 175-185.

- Snedecor, G.W. and Cochran, W.G. (1982). Statistical Methods.7th d. Iowa Univ. Press, Ames. Iowa, USA.

- Stephen, J.L. (2008). A postpartum uterine disease and dairy herd reproductive performance: A review The Vet. J., 176: 102-114.

- Stocker, H. and Waelchli, R.O. (1993). A clinical trial on the effect of prostaglandin F2 alpha on placental expulsion in dairy cattle after caesarean operation. Vet. Rec., 132: 507-508.

- Thatcher, W.W.; Bilby, T.R.; Bartolome, J.A.and Silvestre, F; Staples, G.R. and Stambs, J.E.P. (2006). Strategies for improving fertility in the modern dairy cows. Theriogenology, 65:30-44.

- Wafa, W. M. (2004). Improvingthefertility in Friesian cattle. M.SC. Thesis, Fac. of Agricultural, Al-Azhar University., Egypt.

- Weeks, A. D. (2003). Umbilical oxytocin injection for the treatment of retained placentas. Tropical; 33: 162-163.

- Williamson, N. B.; Quinton, F. W. and Anderson, G.A. (1980). The effect of variations in the interval between calving and first service on the reproductive performance of normal dairy cows. Aust. Vet. J., 56: 477. 
تأثثر طريقة الحقن بالأوكسى توسين أو البروستاجلاندين F2 Fلى إحتباس المشيمة في الأبقار و أداءها التناسلي و الإنتاجي فيما بعد

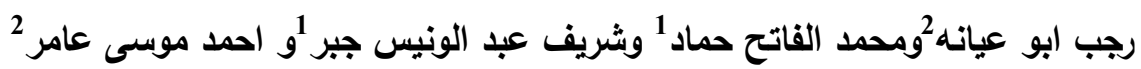

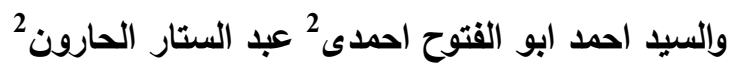
1ققم الإنتاج الحيواني -كلية الزراعة - جامعة طنطا - مصر. 2معهل بحوث الإنتاج الحيواني - مركز البحوث الزراعية - الاقى - الجيزة - مصر .

هذه الدراسة تم إجرائها في مزرعة الثريا للإنتاج الحيواني بكنيسة دمشيت مركز طنطا محافظة الغربية في الفترة من ديسمبر 2016 حتي يوليو 2017 علي 40بقرة فريزيان لديهاحتباس مشيمي مختلفة الأعمار ومواسم الإنتاج

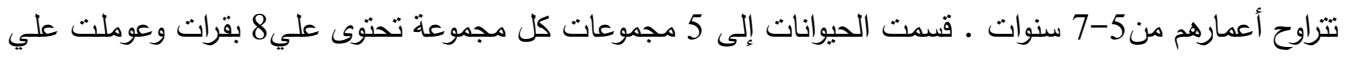

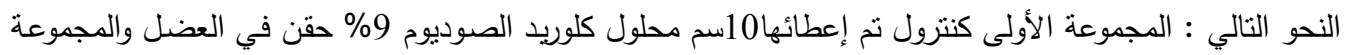
الثانية تم إعطائها 50 وحده دولية من الأوكسيتوسين حقن في العضل والمجموعة الثالثة تم إعطائها 500 ميكروجرام

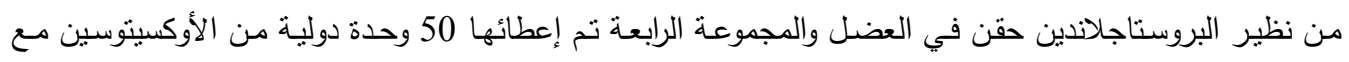
10سم محلول كلوريد الصوديوم 9\% في الثريان السري والمجموعة الخامسة تم إعطائها 500 ميكروجرام من نظير الئلئ

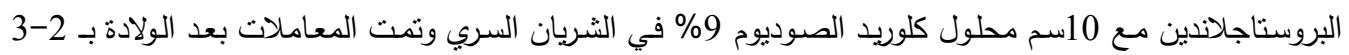
ساعات ونم مقارنة نأثير الحقن العضلي والحقن في الثربان السري.

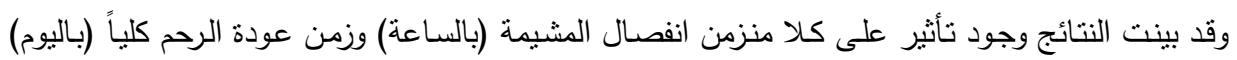

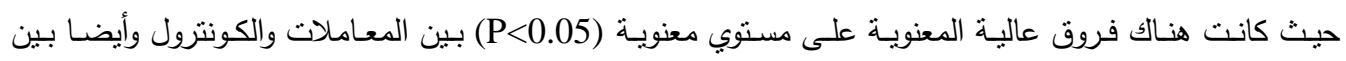

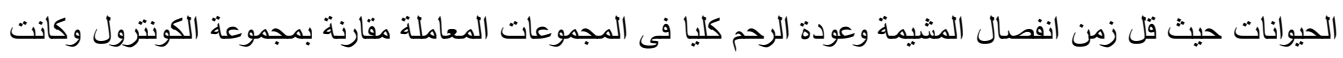

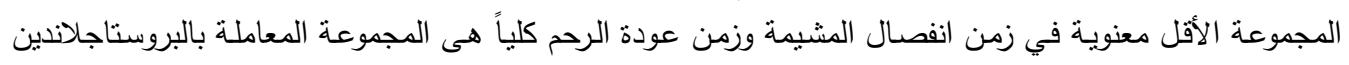

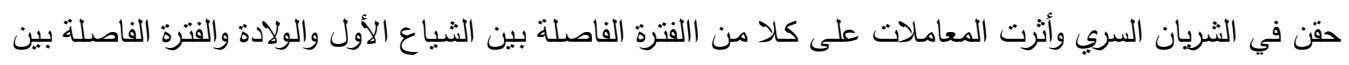

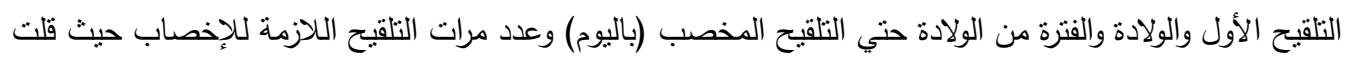

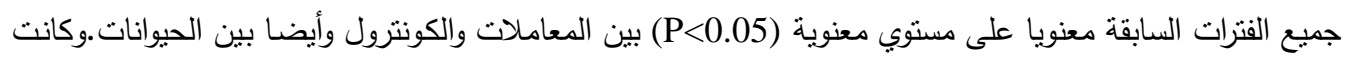

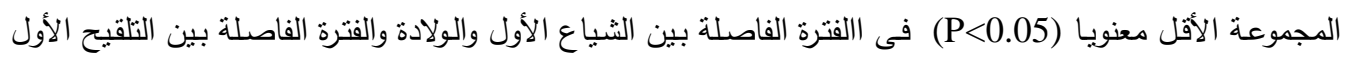
والولادة والفترة من الولادة حتي التلقيح المخصب (باليوم) هى المجي المكوعة المعاملة بالبروستاجلاندين حقن في الشريان السري بينما كانت المجموعة الأقل معنويا (P<0.05) فى طول فترة الأخصاب وعدد مرات التلقيح اللازمة للإخصاب

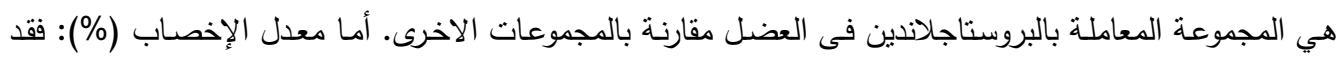

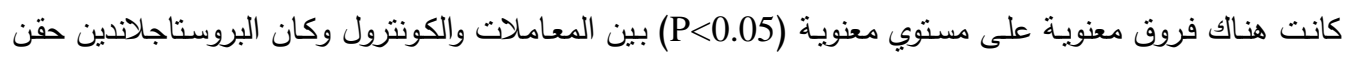
سري الأعلى في معدل الإخصاب مقارنة بباقى المجموعات.

$\overline{\text { Kafrelsheikh Vet. Med. J. Vol. } 17 \text { No. } 1 \text { (2019) }}$ 


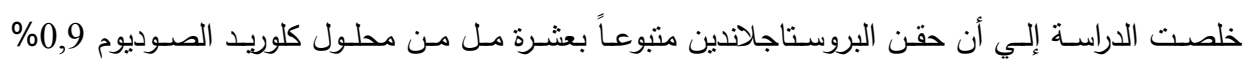

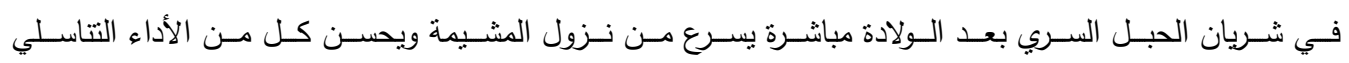

والإنتاجي للأبقار . 